\title{
BioLink
}

Jurnal Biologi Lingkungan, Industri, Kesehatan

Available online http://ojs.uma.ac.id/index.php/biolink

\section{UJI AKTIVITAS ANTIFUNGAL EKSTRAK KULIT PISANG BARANGAN (MUSA ACUMINATA COLLA.) TERHADAP PERTUMBUHAN JAMUR PITYROSPORUM OVALE}

\section{ANTIFUNGAL ACTIVITY TEST OF BARANGAN BANANA PEEL (MUSA ACUMINATA COLLA.) AGAINTS PITYROSPORUM OVALE FUNGI}

\author{
Fioni Chandra, I Nyoman Ehrich Lister*
}

Program Studi Pedidikan Dokter, Fakultas Kedokteran, Universitas Prima Indonesia, Medan

Diterima : 29-01-19; Disetujui : 26-04-19: Diterbitkan : 12-08-19

*Corresponding author: E-mail: *nyoman@unprimdn.ac.id

\begin{abstract}
Abstrak
Perilaku Hidup Bersih dan Sehat (PHBS) penting diupayakan masyakarat untuk mencegah timbulnya berbagai penyakit infeksi salah satunya yang paling umum adalah ketombe atau seborea sika yang diakibatkan oleh pertumbuhan jamur Pityrosporum ovale. Penelitian ini dilakukan untuk memberikan alternatif bahan dari alam yang dapat mengobati ketombe. Penelitian ini menggunakan ekstrak kulit pisang barangan karena merupakan buah khas dari Sumatera Utara yang memiliki kandungan metabolit sekunder yang dapat menghambat pertumbuhan jamur Pityrosporum ovale. Berdasarkan hasil skrining fitokimia ekstrak kulit pisang barangan menunjukkan adanya senyawa-senyawa metabolit sekunder yaitu saponin, tanin, steroida/tritepenoida, flavonoid dan glikosida yang berfungsi sebagai antifungal. Pembuatan ekstrak kulit pisang barangan menggunakan metode maserasi. Uji aktivitas antifungal ekstrak kulit pisang barangan terhadap Pityrosporum ovale dilakukan menggunakan metode difusi cakram. Pada pengujian antifungal diperoleh nilai Kemampuan Hambat Minimum (KHM) yang terbesar pada konsentrasi $1000 \mathrm{mg} / \mathrm{ml}$ dengan rata-rata diameter 11,9 mm. Berdasarkan skala penghambatan uji aktivitas antifungal ekstrak kulit pisang barangan terhadap pertumbuhan jamur Pityrosporum ovale tidak efektif.
\end{abstract}

Kata Kunci: Ekstrak kulit pisang barangan, antifungal, Pityrosporum ovale

\begin{abstract}
Clean and Healthy Lifestyle is essential to be endeavored by society for preventing variety of infectious diseases which one of the most common is dandruff or seborrhea sicca that caused by the growth of Pityrosporum ovale fungi. This research is indicated to provide a better alternative option using ingredient given by nature that can treat dandruff. This research using banana peel extract since it is an original fruit from North Sumatra. The result from phytochemical screening of the banana peel extract shows secondary metabolites which are saponin, tannin, steroid/tritepenoida, flavonoid and glycosides. To produce barangan banana peel extract is by maseration method. Antifungal activity test using barangan banana peel extract towards Pityrosporum ovale is done by disc diffusion method. The antifungal activity test shows the biggest result for Minimum Inhibitory Concentration (MIC) extraction concentration at $1000 \mathrm{mg} / \mathrm{ml}$ with the average diameter of $11,9 \mathrm{~mm}$. According to the inhibitory scale of antifungal activity test of barangan banana peel extract towards the growth of Pityrosporum ovale is ineffective.
\end{abstract}

Key Words: Barangan banana peel extract, antifungal, Pityrosporum ovale

How to Cite: Chandra, F., Lister, I Nyoman. E. (2019). Uji Aktivitas Antifungal Ekstrak Kulit Pisang Barangan (Musa acuminata Colla.) Terhadap Pertumbuhan Jamur Pityrosporum ovale, BioLink : Jurnal Biologi Lingkungan, Industri dan Kesehatan, Vol.6 (1): Hal. 32-40 
Chandra, F., Lister, I Nyoman. E. Uji Aktivitas Antifungal Ekstrak Kulit Pisang Barangan (Musa acuminata Colla.) Terhadap Pertumbuhan Jamur Pityrosporum ovale

\section{PENDAHULUAN}

Penyakit Infeksi adalah masalah utama yang menyebabkan morbiditas diseluruh dunia termasuk di Indonesia. Infeksi jamur termasuk penyakit yang menyerang semua golongan umur dan semua ras yang yang memiliki angka kejadian 20\%-25\% dari seluruh penderita di dunia dan terjadi peningkatan dari tahun ke tahun (Havlickova, et al, 2008). Indonesia yang merupakan negara tropis yang bersuhu panas dan lembab yang mendukung pertumbuhan Jamur, baik yang non-patogen ataupun patogen. Berbagai macam predeposisi yang mendukung peningkatan penderita akibat infeksi Jamur ialah kurangnya kepedulian masyarakat terhadap kebersihan diri dan maraknya penggunaan antibiotik (Candasari, 2011).

Contih penyakit yang terdapat pada kulit kepala adalah Ketombe. Faktor penyebabnya adalah berkembangnya jamur Malassezia, salah satu spesiesnya adalah Pityrosporum ovale yang biasanya merupakan flora yang terdapat pada kulit kepala dan berkembang akibat faktorfaktor pada kulit kepala yang kotor karena kurangnya menjaga kebersihan diri, keringat, kadar minyak berlebih, kadar lemak tinggi, perubuhan suhu, iklim, cuaca, kelembapan, tingkat stress, debu dan penurunan faktor imunitas (Borda, 2015). Sekarang, oleh karena maraknya penjual obat-obat kimiawi yang bebas dijual dan dipromosikan oleh media massa menimbulkan resistensi dan efek samping bagi obat antifungi, Keresahan ini yang memunculkan usaha untuk mencari agenagen antifungi yang lebih baik, toksisitas yang lebih rendah, bahan alami dan ramah lingkungan. Oleh karena itu digunakan tanaman sebagai pengobatan alternaitif, pemanfaatan tanaman untuk pengobatan telah lama dikenal oleh masyarakat (Dalimartha, 2008).

Diantara bahan alami yang digunakan sebagai obat antifungi ialah Kulit Pisang Barangan (Musa paradisiaca Linn.), Berdasarkan penelitian Ighodaro (2012) ekstrak kulit Musa paradisiaca Linn. dengan konsentrasi 100 mg/ml telah terbukti dalam menghambat jenis jamur seperti Aspergillus niger (Ighodaro, 2012). Tapi pada penelitian yang dilakukan Chadbuck (2013) ekstrak kulit Musa paradisiaca Linn. sama sekali tidak memiliki daya hambat terhadap pertumbuhan jamur C. Albicans. (Chadbuck, 2013)

Tujuan penelitian ini adalah agar Kulit Pisang Barangan (Musa paradisiaca Linn), dapat dikembangkan sebagai obat antifungi yang memiliki tingkat toksisitas yang lebih rendah. Dan mudah dicari di masyarakat. 


\section{METODE PENELITIAN}

Penelitian ini merupakan penelitian eksperimen laboratorik dengan metode maserasi dan difusi cakram untuk melihat aktivitas antifungal ekstrak kulit pisang barangan (Musa acuminata Colla.) terhadap pertumbuhan jamur

Pityrosporum ovale

Alat-alat yang digunakan pada penelitian ini meliputi kamera digital, pisau, gunting, talenan, penggaris, jerigen, timbangan, blender, kulkas, bola lampur pijar 40 watt, toples kaca, botol sampel, loyang, kertas saring, kertas perkamen kajang, gelas ukur, beaker glass, tabung reaksi, rak tabung reaksi, cawan porselain, penjepit tabung, pipet tetes, pipet mikro, pinset, spatula, jangka sorong, jarum ose, kapas, kasa steril, pencandang kertas, corong kaca, lemari pengering, mesin rotary evaporator, waterbath, lemari asam, otoklaf, inkubator, Biological Safety Cabinet, lemari pendingin, neraca analitik, oven.

Bahan yang digunakan pada penelitian ini adalah kulit pisang barangan. Bahan kimia yang digunakan pada penelitian ini melitputi etanol 96\%, methanol, asam klorida pekat, asam sulfat pekat, besi (III) klorida, timbal (II) asetat, kloroform, isopropanol, amil alkohol, aquades, etanol, n-heksana, pereaksi meyer, dragendorff, bourchardat, Lieberman Bourchart, isopropanol, kloroform, molish, dimetil sulfoksida (DMSO), serbuk potato dextrose agar (PDA), nutrient broth, spiritus, alkohol 70\%, serta jamur Pityrosporum ovale yang diperoleh dari Laboratorium Mikrobiologi Universitas Sumatera Utara.

\section{Tahapan Penelitian}

\section{a. Persiapan Sampel}

Kulit pisang barangan yang baru diperoleh dari pasar dipisahkan terlebih dahulu dari batang dan disisihkan satu malam agar getah jatuh. Kemudian, bersihkan dari kotoran seperti debu dan getah yang dicuci dengan air bersih, Kulit pisang barangan dipisahakan dari buah kemudian dirajang sekitar $1 \mathrm{~cm}$ dan ditimbang berat basahnya, dikeringkan didalam lemari pengering dan ditimbang beratnya. Simplisia di blender menjadi serbuk dan disimpan dalam toples kaca yang diberi stiker label lalu disimpan pada tempat yang terhindari dari cahaya matahari.

\section{b. Skrining Fitokimia}

\section{Pemeriksaan Saponin}

Ekstrak kulit pisang barangan diambil sebanyak 0,5 g menggunakan spatula ke dalam tabung reaksi, kemudian ditambahkan $10 \mathrm{ml}$ air panas. Didinginkan dengan pada rak tabung reaksi yang setelah dingin dikocok kuat-kuat selama 10 detik. Jika terlihat busa setinggi 1 - 10 
Chandra, F., Lister, I Nyoman. E. Uji Aktivitas Antifungal Ekstrak Kulit Pisang Barangan (Musa acuminata Colla.) Terhadap Pertumbuhan Jamur Pityrosporum ovale

cm yang stabil selama lebih dari 10 menit dan tidak hilang dengan penambahan 1 tetes asam klorida $2 \mathrm{~N}$ berarti menunjukkan adanya saponin (Depkes RI, 1995).

\section{Pemeriksaan Tanin}

Ekstrak kulit pisang barangan diambil sebanyak 1 g menggunakan spatula ke dalam tabung reaksi, kemudian ditambahkan $100 \mathrm{ml}$ air biasa yang dididihkan didalam waterbath selama 3 menit kemudian didinginkan pada rak tabung reaksi lalu disaring dengan kertas saring. Pada filtrat kemudian ditetesi 1- 3 tetes pereaksi besi (III) Klorida 1\%. Jika terdapat warna hijau kehitaman atau biru kehitaman menunjukkan terdapatnya tanin (Farnsworth, 1996)

\section{Pemeriksaan Steroida/Tritepenoida}

Ekstrak kulit pisang barangan diambil sebanyak 1 g menggunakan spatula ke dalam tabung reaksi, kemudian dimaserasi dengan $20 \mathrm{ml}$ n-heksana selama 2 jam dan di tutup dengan plastic wrap lalu disaring dengan kertas saring dan filtrat dipindahkan dari tabung reaksi ke cawan porselain untuk proses penguapan dimana sisa filtrat yang mengering ditetesi dengan beberapa tetes pereaksi Liebermann Bourchart. Timbulnya warna biru atau biru hijau menunjukkan terdapatnya steroida, sedangkan timbulnya warna merah, merah muda atau ungu menunjukkan

terdapatnya triterpenoida (Harborne, 1987).

4. Pemeriksaan Flavonoid

Ekstrak kulit pisang barangan diambil sebanyak $10 \mathrm{~g}$ menggunakan spatula ke dalam tabung reaksi, kemudian ditambahkan $10 \mathrm{ml}$ air panas, dididihkan dalam waktu 5 menit yang kemudian langsung disaring menggunakan kertas saring. Kemudian tabung reaksi yang terdapat $5 \mathrm{ml}$ filtrat yang dibawa ke lemari asam dengen penjepit tabung reaksi ditambahkan 0,1 gr serbuk magnesium, 2 ml amil alcohol dan $1 \mathrm{ml}$ asam klorida pekat, dikocok dan dibiarkan memisah. Flavonoid dinyatakan positif jika terjadi warna merah atau jingga atau kuning pada lapisan amil alkohol (Depkes RI, 1995).

5. Pemeriksaan Alkaloid

Ekstrak kulit pisang barangan diambil sebanyak 0,5 g menggunakan spatula ke dalam tabung reaksi, lalu ditambahkan $1 \mathrm{ml}$ asam klorida $2 \mathrm{~N}$ dan 9 $\mathrm{ml}$ air suling, dipanaskan di atas waterbath selama 2 menit, didinginkan di rak tabung reaksi dan disaring dengan menggunakan kertas saring biasa. Filtrat yang diperoleh digunakan untuk uji alkaloid dibagi ke dalam 3 tabung reaksi dengan sama rata.

Pada masing-masing tabung reaksi:

- Tabung 1, dimasukan 2 tetes pereaksi Meyer 
- Tabung 2, dimasukan 2 tetes pereaksi menunjukkan terdapatnya ikatan gula

Bourchardat

- Tabung 3, dimasukan 2 tetes pereaksi

Dragendorff.

Alkaloid positif jika terdapat kekeruhan atau endapan minimal dua dari tiga percobaan di atas (Depkes RI, 1995).

\section{Pemeriksaan Glikosida}

Ekstrak kulit pisang barangan diambil sebanyak 3 g menggunakan spatula dan dimasukan tabung reaksi, lalu disari dengan menggunakan $30 \mathrm{ml}$ campuran etanol 95\% dan air (7:3) dan 10 $\mathrm{ml}$ asam klorida $2 \mathrm{~N}$, lalu direfluks selama 2 jam, didinginkan dan disaring. Diambil $20 \mathrm{ml}$ filtrat yang kemudian ditambah 25 $\mathrm{ml}$ air suling dan 25 timbal (II) asetat 0,4 M, dikocok, lalu didiamkan 5 menit dan disaring. Filtrat disari menggunakan $20 \mathrm{ml}$ campuran isopropanol dan kloroform (2:3), lakukan sebanyak 3 kali. Sari air dikumpulkan dan diuapkan pada temperature sekitar $50^{\circ} \mathrm{C}$. sisanya dilarutkan kedalam $2 \mathrm{ml}$ metanol. Larutan sisa dapat digunakan untuk percobaan selanjutnya: 0,1 ml larutan percobaan dimasukkan ke tabung reaksi dan diuapkan menggunakan penangas air. Sisanya ditambahkan 5 tetes pereaksi Molish dan $2 \mathrm{ml}$ air. Secara perlahan-lahan tambahkan $2 \mathrm{ml}$ asam sulfat pekat melalui dinding tabung, jika terbentuk cincin berwarna ungu pada batas kedua cairan
(Depkes RI, 1995).

\section{c. Uji Aktivitas Antifungal}

1. Pembuatan Larutan Uji Ekstrak Kulit Pisang Barangan dengan Berbagai Konsentrasi

Sebanyak 1 g ekstrak kulit pisang barangan ditimbang dalam vial volume 15 ml yang telah ditara terlebih dahulu dan telah dikalibrasi pada batas $10 \mathrm{ml}$, kemudian ditambahkan DMSO (dimetil sulfoksida) diaduk sampai sampel larut dan ditambahkan sisa DMSO sampai batas kalibrasi, maka konsentrasi ekstrak kulit pisang barangan adalah $100 \mathrm{mg} / \mathrm{ml}$ kemudian dibuat pengenceran selanjutnya sampai diperoleh konsentrasi ekstrak kulit pisang barangan $100 ; 200 ; 300 ; 400 ; 500$; $600 ; 700 ; 800 ; 900 ; 1000 \mathrm{mg}$ per $1 \mathrm{ml}$ (Harahap, 2015).

2. Pengujian Aktivitas Antifungal Ekstrak Kulit Pisang Barangan Terhadap Pityrosporum ovale

Kedalam cawan petri steril dimasukkan $1 \mathrm{ml}$ inokulum, kemudian ditambahkan $15 \mathrm{ml}$ media PDA steril yang telah dicairkan. Kemudian cawan petri dihomogenkan di atas permukaan meja (Biologival safety cabinet) agar media dan suspensi jamur tercampur rata dan dibiarkan sampai memadat. Pada permukaan media yang sudah memadat diletakkan pencadang kertas yang telah direndam dalam larutan uji ekstrak kulit pisang barangan, sebagai kontrol 
Chandra, F., Lister, I Nyoman. E. Uji Aktivitas Antifungal Ekstrak Kulit Pisang Barangan (Musa acuminata Colla.) Terhadap Pertumbuhan Jamur Pityrosporum ovale

digunkana DMSO, ditutup cawan petri dan 2 Tanin

dibungkus. Didiamkan 10 - 15 menit. Lalu inkubasi dalam inkubator disuhu $25^{\circ} \mathrm{C}$ selama 48 jam. Pengukuran uji aktivitas antifungal pada ekstrak kulit pisang barangan diukur diameter zona bening di sekitar pencadang menggunakan jangka sorong. Percobaan ini dilakukan dengan pengulangan 3 kali (Mahataranti, 2012).

\section{HASIL DAN PEMBAHASAN}

a. Hasil Skrining Fitokimia

Hasil skrining fitokimia terhadap ekstrak kulit pisang barangan dapat dilihat pada tabel 1.1 berikut ini.

Tabel 1. Hasil skrining fitkomia ekstrak kulit pisang barangan.

\begin{tabular}{ccc}
\hline No. & Pemeriksaan & Hasil \\
\hline 1 & Saponin & + \\
\hline
\end{tabular}

3 Steroida/Tritepenoida

$4 \quad$ Flavonoid

$5 \quad$ Glikosida

$6 \quad$ Alkaloida

\section{Keterangan:}

(+) Positif : Mengandung golongan senyawa

(-)Negatif : Tidak mengandung golongan senyawa

Hasil pada Tabel 1. di atas menunjukkan bahwa ekstrak kulit pisang barangan memiliki berbagai senyawa metabolit sekunder senyawa flavonoid, saponin, tanin dan steroida/tritepenoida.

b. Uji Aktivitas Antifungal Ekstrak Kulit Pisang Barangan Terhadap Jamur Pityrosporum ovale

Hasil pengukuran diameter daerah hambat ekstrak kulit pisang barangan dapat dilihat pada Tabel 2.

Tabel 2. Data hasil uji aktivitas antifungal ekstrak kulit pisang barangan terhadap jamur

\begin{tabular}{ccc}
\multicolumn{2}{c}{ Pityropsorum ovale } \\
\hline No & $\begin{array}{c}\text { Konsentrasi ekstrak kulit pisang } \\
\text { barangan }(\mathrm{mg} / \mathrm{ml}\end{array}$ & $\begin{array}{c}\text { Rata-rata diameter hambat } \\
\text { pertumbuhan jamur }(\mathrm{mm})\end{array}$ \\
\hline 1 & 1000 & 11,9 \\
2 & 900 & 11 \\
3 & 800 & 10,2 \\
4 & 700 & 9,2 \\
5 & 600 & 8,2 \\
6 & 500 & 7 \\
7 & 400 & - \\
8 & 300 & - \\
9 & 200 & - \\
10 & 100 & - \\
\hline
\end{tabular}

Keterangan:

- : Tidak terdapat daerah hambatan pertumbuhan jamur 


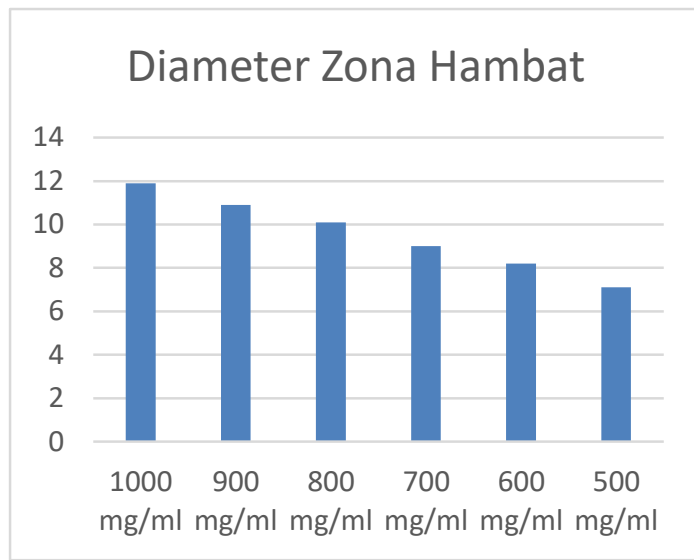

Gambar 1. Diameter Zona Hambat

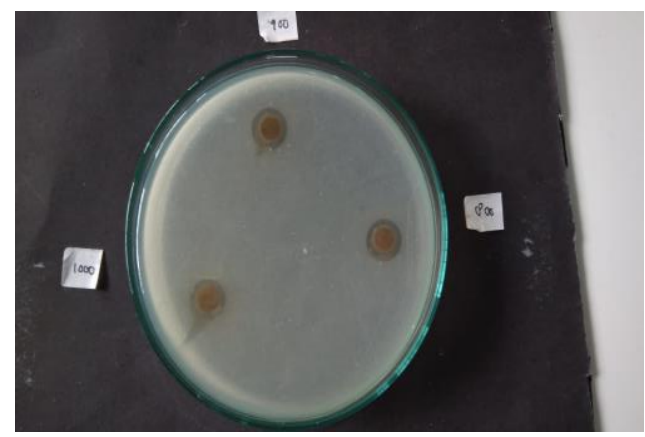

Gambar 2. Zona hambat jamur

Berdasarkan Tabel 1.1 diperoleh daya hambat pada konsentrasi ekstrak nilai hambat minimum (KHM) pada kulit pisang barangan 500; 600; 700; 800; konsentrasi ekstrak kulit pisang barangan 900; $1000 \mathrm{mg} / \mathrm{ml}$ masuk ke dalam $500 \mathrm{mg} / \mathrm{ml}$ dengan rata-rata diameter kategori penghambatan tidak aktif, hambat $7 \mathrm{~mm}$ dan nilai hambatan terbesar sedangkan pada konsentrasi ekstrak kulit ditunjukkan pada ekstrak kulit pisang pisang barangan 100; 200; 300; 400 barangan $1000 \mathrm{mg} / \mathrm{ml}$ dengan diameter $\mathrm{mg} / \mathrm{ml}$ tidak memiliki aktivitas antifungal hambat 11,9 mm. Aktivitas antijamur (Silvia, 2013).

dinilai dengan mengukur daerah bening

Hasil ini memberikan hasil yang penghambatan pertumbuhan jamur di sama dengan penelitian Chadbuck(2013) sekitar pencadang, dan hasilnya yang juga tidak efektif sebagai antifungal diklasifikasikan menurut skala terhadap jamur C. Albicans. Penghambatan penghambatan: 9-12 mm tidak aktif, 13 - pertumbuhan jamur disebabkan oleh $17 \mathrm{~mm}$ cukup aktif, $18 \mathrm{~mm}$ aktif dan diatas adanya senyawa metabolit sekunder pada $18 \mathrm{~mm}$ sangat aktif. Hasil pengukuran ekstrak kulit pisang barangan seperti 
Chandra, F., Lister, I Nyoman. E. Uji Aktivitas Antifungal Ekstrak Kulit Pisang Barangan (Musa acuminata Colla.) Terhadap Pertumbuhan Jamur Pityrosporum ovale

senyawa tanin yang cara kerjanya bahan alami yang mudah dicari dalam mengendapan protein dan dapat merusak masyarkat sebagai antifungal.

membran sel yang menyebabkan pertumbuhan fungi menjadi terhambat, senyawa saponin mempunyai efek antifungi yang sangat baik dengan adanya gugusan monosakarida dan turunan saponinnya memiliki fungsi sebagai deterjen sehingga dapat merusak membran sitoplasma dan dapat membentuk jamur (Mozer, 2015)

Sedangkan senyawa metabolit sekunder flavonoid mempunyai cara kerja yaitu dengan mengikat fosfolipid sehingga mengganggu permeabilitas membrane sel fungi. Peningkatan permeabilitas diakibatkan oleh terganggunya fungsi membrane sel karena perubahan komposisi protein yang menyebabkan kerusakan sel dan kemudian menyebabkan kematian jamur Pityrosporum ovale.

\section{SIMPULAN}

Hasil uji aktivitas antifungal dari ekstrak kulit pisang barangan tersebut menunjukkan bahwa ekstrak kulit pisang barangan tidak efektif menghambat pertumbuhan jamur Pityrosporum ovale.

Disarankan kepada peneliti selanjutnya untuk melakukan uji aktivitas antifungal pada ekstrak buah lainnya sehingga masyarakat dapat mengunakan

UCAPAN TERIMAKASIH

Ucapan terimakasih penulis ucapkan kepada Rektor Universitas Prima Indonesia, Dr Chrismis Novalinda Ginting, M.Kes, dan Dekan Fakultas Kedokteran dr Linda Chiuman, M.K.M. Ucapan terima kasih juga kepada pembimbing utama Dr. dr. I Nyoman Ehrich Lister,M.Kes., AIFM. atas ide dan motivasi dalam penelitian ini, kepada ketua dan anggota laboratorium Biologi Farmasi, Fakultas Farmasi, Universitas Sumatera Utara, yang ikut membantu dalam pelaksanaan penelitian.

\section{DAFTAR PUSTAKA}

Borda, J.L., dan Wikramanayake, C.T. (2015). Seborrheic Dermatitis and Dandruff : A Comprehensive Review. Journal of Clinical $\mathcal{E}$ Investigative Dermatology. 3(2): 5.

Candasari, A., Romas, M.A. and Astuti, O.R., (2011). Uji Daya Antimikroba Ekstrak Etanol Daun Sirih Merah (Piper Crocatum Ruiz \& Pav.) Terhadap Pertumbuhan Staphylococcus aureus ATCC 11229 dan Candida albicans ATCC 10231 Secara In Vitro. Biomedika, 4(1).

Chadbuck ZAG, Al-Charrack AH, Hindi NKK, Hindi SKK. Antimicrobial Effect of Aqueous Banana Peel Extraxt. Iraq Pharmaceutical Sciences 2013; 1:73-75.

Dalimartha, Setiawan., (2008). Atlas Tumbuhan Obat Indonesia. Jilid 4, Jakarta: Puspa Swara, hal 87-89.

Depkes RI. (1995). Farmakope Indonesia. Edisi Keempat. Jakarta: Departemen Kesehatan RI. Halaman 112, 413, 595, 891-899.

Farnsworth, N.R. (1996). Biological and Phytochemical Screening of Plants. Journal of Pharmaceutical Sciences. 55 (3) : 263.

Harborne, J.B. (1987). Metode Fitokimia, Penuntun Cara Modern Menganalisa Tumbuhan. Terjemahan Kosasih Padmawinata. Edisi II. Bandung: ITB Press. Hal. 47-102, 152-153. 
Havlickova, B. et al. (2008). Epidemiological Trends in Skin Mycoses Worldwide. Journal compilation. Mycoses, 51 (Suppl. 4), 2-15 3. : Germany: Blackwell Publishing Ltd.

Ighodaro, O. Evaluation Study on Nigerian Species of Musa paradisiaca Peels: Phytochemical Screening, Proximate Analysis, Mineral Composition and Antimicrobacterial Activities. Nigeria : Lead City University. $2012: 17-20$.

Kumar KPS, Bhowmik D, Duraivel S, Umadevi M. Traditional and Medicinal Uses of Banana. Journal Pharmacognosy and Phytochemistry 2012; 1(3):51-53.

Mahataranti, N., Astuti, Y.I., dan Aariningdhiani, B. (2012). Formulasi Shampo Antiketombe Ekstrak Etanol Seledri (Apium graveolens L) dan Aktivitasnya Terhadap Jamur
Pityrosporum ovale. Jurnal Farmasi. 9(2): 132.

Robinson, T. (1995). The Organic Constituents of High Plant. Edisi keempat. New York: University of Massachusetts. Terjemahan: Kosasih Padmawinata. Kandungan Organik Tumbuhan Tinggi. Edisi keempat. Bandung: ITB. Halaman 71-72, 191-193.

Silvia, A.C.O., Santana, E.F., Saraiva, A.M., Countinho, F.N., Castro, R.H.A., Pisciottano, M.N.C., Amorim, E.L.C., dan ALbuquerue, U.P. (2013). Which Approach Is More Effective in the Selection of Plants with Antimicrobial Activity. Journal of Hindawi Publishing Corporation. Brazil: Cidade Universitas. Halaman 3. 